\title{
The emergent fouling population after severe eutrophication in the Mar Menor coastal lagoon
}

\author{
Jessica Sandonnini ${ }^{\mathrm{a}}$, Yoana Del Pilar Ruso ${ }^{\mathrm{a}}$, Emilio Cortés Melendreras ${ }^{\mathrm{b}}$, \\ Carmen Barberá ${ }^{\mathrm{a}}$, Iris E. Hendriks ${ }^{\mathrm{c}}$, Diego Kurt Kersting ${ }^{\mathrm{d}}$, Francisca Giménez \\ Casalduero ${ }^{\mathrm{a}, *}$ \\ ${ }^{a}$ Department of Marine Science and Applied Biology, Carretera de San Vicente del Raspeig, s/n, 03690 San Vicente del Raspeig, Alicante, Spain \\ ${ }^{\mathrm{b}}$ Murcia University Aquarium, Cuartel de Artillería P. 4, C/ Cartagena s/n, 30002 Murcia, Spain \\ c Global Change Department, Mediterranean Institute for Advanced Studies (CSIC-UIB), Esporles (Mallorca), Spain \\ ${ }^{\mathrm{d}}$ Departament de Biologia Evolutiva, Ecologia $i$ Ciències Ambientals, Facultat de Biologia, IRBIO, Universitat de Barcelona, 08028, Spain
}

\section{A R T I C L E I N F O}

\section{Article history:}

Received 6 March 2020

Received in revised form 26 February 2021

Accepted 1 March 2021

Available online 3 March 2021

\section{Keywords:}

Coastal lagoons

Mar Menor

Polychaetes

Fouling, eutrophication

\begin{abstract}
A B S T R A C T
Mar Menor is one of the largest coastal lagoons in the Mediterranean basin. Over the years, Mar Menor has suffered a significant environmental degradation due to multiple factors with anthropogenic origin. The transformation from a rain-fed basin to intensive irrigated agriculture has led to an rise in the water inflow and nutrients in the basin, which has provoked severe eutrophication. The increase in nutrients led to changes in the structure and function of the lagoon ecosystems. The epibenthic and suspension feeder organisms have benefited from this imbalance, proliferating and reaching a high population density. The composition and abundance of the species assemblage found in the sub-coastal bottoms of the coastal lagoon after the environmental crisis occurred in 2016, using artificial settlement structures. The variation in community density and affinity between sampling sites in 2017 and 2018, were determined. A total of 31 species belonging to 27 genera and 7 phyla were observed in 11 samples. The best represented class are polychaeta (Phylum Annelida) with 11 identified species. The genus with the greatest species richness was Hydroides with two species: H. dianthus (Verrill, 1873), and $H$. elegans (Haswell, 1883), both of them considered potentially invasive and opportunistic species followed by the genus Serpula, with two species: S. vermicularis (Linnaeus, 1767), and S. concharum (Langerhans, 1880) and the genus Branchiomma was represented with another exotic invasive species, B. boholense (Grube, 1878), which is only found in collectors in 2018. These results have allowed to increase the knowledge about the effect of eutrophication in the structure of the fouling community in the assemblage succession in the Mar Menor coastal lagoon.
\end{abstract}

(C) 2021 The Authors. Published by Elsevier B.V. This is an open access article under the CC BY-NC-ND license (http://creativecommons.org/licenses/by-nc-nd/4.0/).

\section{Introduction}

The Mar Menor is a hypersaline coastal lagoon in the Western Mediterranean Sea and is included in the RAMSAR List of International Importance Wetlands. It is also a Special Protection Area of Mediterranean Importance (SPAMI), a Special Protection Area for Wild Birds (SPAs) and a Site of Community Importance (SCI) integrated into the Natura 2000 Network (EU Habitats Directive) (Velasco et al., 2006). From a socioeconomic point of view, this ecosystem has provided numerous goods and services, and consequently, different activities such as agriculture, tourism, fishing or former mining operations have converged for decades (Conesa and Jiménez-Cárceles, 2007; Martinez-Fernandez et al., 2014). The lagoon has been affected for years by continuous

\footnotetext{
* Corresponding author.

E-mail address: francisca.gimenez@ua.es (F. Giménez Casalduero).
}

inputs of water with high concentrations of nutrients from agricultural and sewage source (Martinez Fernandez and Esteve, 2000; Pardo et al., 2004; Carreño et al., 2008; Gómez, 2017). As a consequence of this massive supply of nutrients, midway through 2015 , the water quality showed a radical change due to a massive proliferation of phytoplankton (Aguilar Escribano et al., 2016). The Mar Menor reached a stage of severe eutrophication that ended in an "environmental collapse" which resulted in $85 \%$ of seagrass meadows lost (Belando et al., 2017). The absence of oxygen caused a massive mortality of benthic organisms (molluscs, polychaetes, etc.). Critically endangered species like the bivalve Pinna nobilis suffered a drastic reduction in their populations (Kersting et al., 2020; Giménez-Casalduero et al., 2020). Other endangered species with limited mobility such as seahorses (Hippocampus guttulatus), not only decreased their populations, but the survivors were also relegated to specific areas of the shoreline lagoon (Giménez-Casalduero et al., 2020). All sessile 
infauna and epifauna located in areas below three metres depth (a key threshold value in this eutrophication episode), died due to hypoxia and the drop in $\mathrm{pH}$ values generated by the decomposition of dead plant biomass. During the second half of 2017, some recovery of meadows of the macrophyte Caulerpa prolifera were observed (Ruiz et al., 2019) along with an extraordinary growth of suspension-feeders serpulidae polychaetes (Sandonnini et al. 2021). These events appear to be a response to the high availability of suspended organic particles and the availability of $\mathrm{CO}_{2}$ for fixation of calcium carbonate (Mayer-Pinto and Junqueira, 2003). These worms with calcareous tubes generate micro-reefs that increase the heterogeneity of the sediment (Swan, 1950; Álvarez Rogel et al., 2016).

The main factors that determine the composition of a fouling community in an eutrophicated environment are the recruitment capacity of the species, intra and interspecific competition and environmental conditions (Richmond and Seed, 1991). Eutrophication causes a decrease in diversity and favours the development of opportunistic species (Murray and Littler, 1978; Pearson and Rosenberg, 1978; Gray, 1981; Hargrave and Thiel, 1983; Moran and Grant, 1991; Meyer-Reil and Koster, 2000). Some authors suggest that changes in the fouling community in eutrophic areas are caused by competition between tolerant and non-tolerant species rather than the toxic conditions themselves (Rastetter and Cooke, 1979; Moran and Grant, 1991).

This research evaluated the fouling community that emerged in the Mar Menor coastal lagoon after the environmental crisis occurred in 2016. The structuring species of the fouling were identified in two moments of the eutrophication process in the lagoon.

\section{Material and methods}

\subsection{Study area and experimental design}

The Mar Menor, with an area of about $135 \mathrm{~km}^{2}$ is considered the largest coastal lagoon in the Western Mediterranean (Fig. 1). This hypersaline lagoon is relatively shallow, with an average depth of 3.5 metres and a maximum depth of $6.5 \mathrm{~m}$. The lagoon is delimited by La Manga, a $22 \mathrm{~km}$ long sandy bar crossed by five canals regulating the exchange of water with the Mediterranean, and it has a salinity range of between 42 and 47 psu. Under normal conditions the community was dominated by euryhaline and eurytherm species (Marín-Guirao et al., 2005).

During 2017 and 2018 two shallow areas of the lagoon that are $10 \mathrm{~km}$ apart were evaluated: (i) B: Barón (N37 $41^{\prime} 45.9^{\prime \prime}$ W $0^{\circ} 45^{\prime} 9.48^{\prime \prime}$ ) and, (ii) E: Encañizadas (N 37 46 $9.69^{\prime \prime} \mathrm{W} 0^{\circ}$ $45^{\prime} 7.79^{\prime \prime}$ ) (Fig. 1). Both study sites were characterized by muddy sand sediment, covered by a mixed Caulerpa prolifera (Forsskal) Lamouroux and Cymodocea nodosa Asch meadow.

Artificial collectors were used to assess the fouling community settled in 2017 and 2018. Collectors consisted of plastic mesh bags ( 81 volume and $0.8 \mathrm{~cm}$ mesh-size) filled with $1 \mathrm{~m}^{2}$ tangled nylon fishing net. The bags were attached to a main rope fixed to a concrete mooring and kept vertical by a submerged buoy (Kersting \& García-March 2017, (Kersting et al., 2020). Each year collectors were installed at each location (B and E) in July and recovered in November. A total of twelve collectors ( 3 collectors per site) were installed covering a depth range of 1.5-2.5 m. During 2018, one collector situated in Las Encañizadas disappeared, probably due to vandalism.

The collectors were manually gathered by scuba diving and placed in a container with sea water during transport to the laboratory, where they were cleaned with a brush and the captured organisms were fixed in $10 \%$ formaline solution. Before identification, the samples were washed in a sieve with $0.5 \mathrm{~mm}$
Table 1

Salinity, depth and temperature data of localities (Barón and Encañizadas) for 2017 and 2018.

\begin{tabular}{lllll}
\hline Locality & Year & Temp. $\left({ }^{\circ} \mathrm{C}\right)$ & Depth $(\mathrm{m})$ & Salinity $(\mathrm{psu})$ \\
\hline Baron & 2017 & 28.2 & $1.5-2.2$ & 44.9 \\
Encañizada & 2017 & 28.94 & $1.5-2.5$ & 43.9 \\
Baron & 2018 & 28.2 & $1.5-2.2$ & 44.92 \\
Encañizada & 2018 & 28.94 & $1.5-2.5$ & 43.9 \\
\hline
\end{tabular}

mesh size. Once rinsed, the organisms were sorted with the help of a stereo microscope and were classified and stored in $70 \%$ alcohol. The organisms were identified at the highest taxonomic level possible (Zibrowius, 1992, 1994; Zibrowius and Thorp, 1989; Ten Hove and Wolf, 1984; TenHove and Kupriyanova, 2009). Taxa were listed according to the World Register of Marine Species (WoRMS) nomenclatural system (WoRMS Editorial Board, 2019).

The amount of calcium carbonate generated during the study period by serpulidae was estimated. Also, a ratio between dry weight of the Polychaeta tube structure and the live specimens was calculated. The empty tubes were weighed with a digital scale with an accuracy of $0.001 \mathrm{~g}$. Before weighing them, the tubes were dried in a laboratory oven at $80{ }^{\circ} \mathrm{C}$ for $48 \mathrm{~h}$.

The Cymodoce truncata Leach, 1814 and Sphaeroma serratum Fabricius, 1787 biomass was also estimated. The organisms were dried at $80{ }^{\circ} \mathrm{C}$ for $72 \mathrm{~h}$ and then weighed. The total percentage was obtained by calculating the average in grams of the isopods found in the different collectors for the different years and locations.

\subsection{Data analysis}

Different ecological parameters were used to analyse the community structure: Number of species (S); Shannon-Wiener index (H') (Shannon and Weaver, 1963); Margalef specific richness in$\operatorname{dex}(\mathrm{d})$ and the equitability Pielou index (J') (Magurran, 1988). To evaluate the differences in the fouling community, with particular focus on the polychaeta assemblages. A multivariate analysis was used to analyse the composition and distribution pattern of the community, considering both locations and years. CLUSTER procedures and non-multidimensional scaling (nMDS), with untransformed data, before the application of the Bray-Curtis similarity index, were used to evaluate the similarity between locations and years. SIMPER analysis ("percentages of similarity/dissimilarity") identified the most common and dominant species among the replicates. The analytical work was carried out with PRIMER V6 (Plymouth Routines in Multivariate Ecological Research) (Clarke and Warwick, 2001).

\section{Results}

During the study period, the water column had a salinity ranging from 43 to $44 \mathrm{PSU}$, and an average temperature of $28^{\circ} \mathrm{C}$ (Table 1). A total of 14.680 individuals and 31 different taxa were identified during the full study period (2017 and 2018).

The number of taxa and organisms abundance changed during both studied years. The phylum Annelida (class Polychaeta) was the most represented, with eleven identified species. Their relative abundance increased from $17.6 \%$ in 2017 to $43.5 \%$ in 2018. The richness of the Arthropoda phylum was lower, with only six species identified but its relative abundance reached the highest values of all groups (85.2\%) in 2017, decreasing to $45.2 \%$ during 2018 . Four species were identified in the phylum Cnidaria with an increase of their relative abundance over time (2017: 2.5\%; 2018: 4.5\%). The following phyla were founded only in 2018 samples: Mollusca, with five identified species and a 

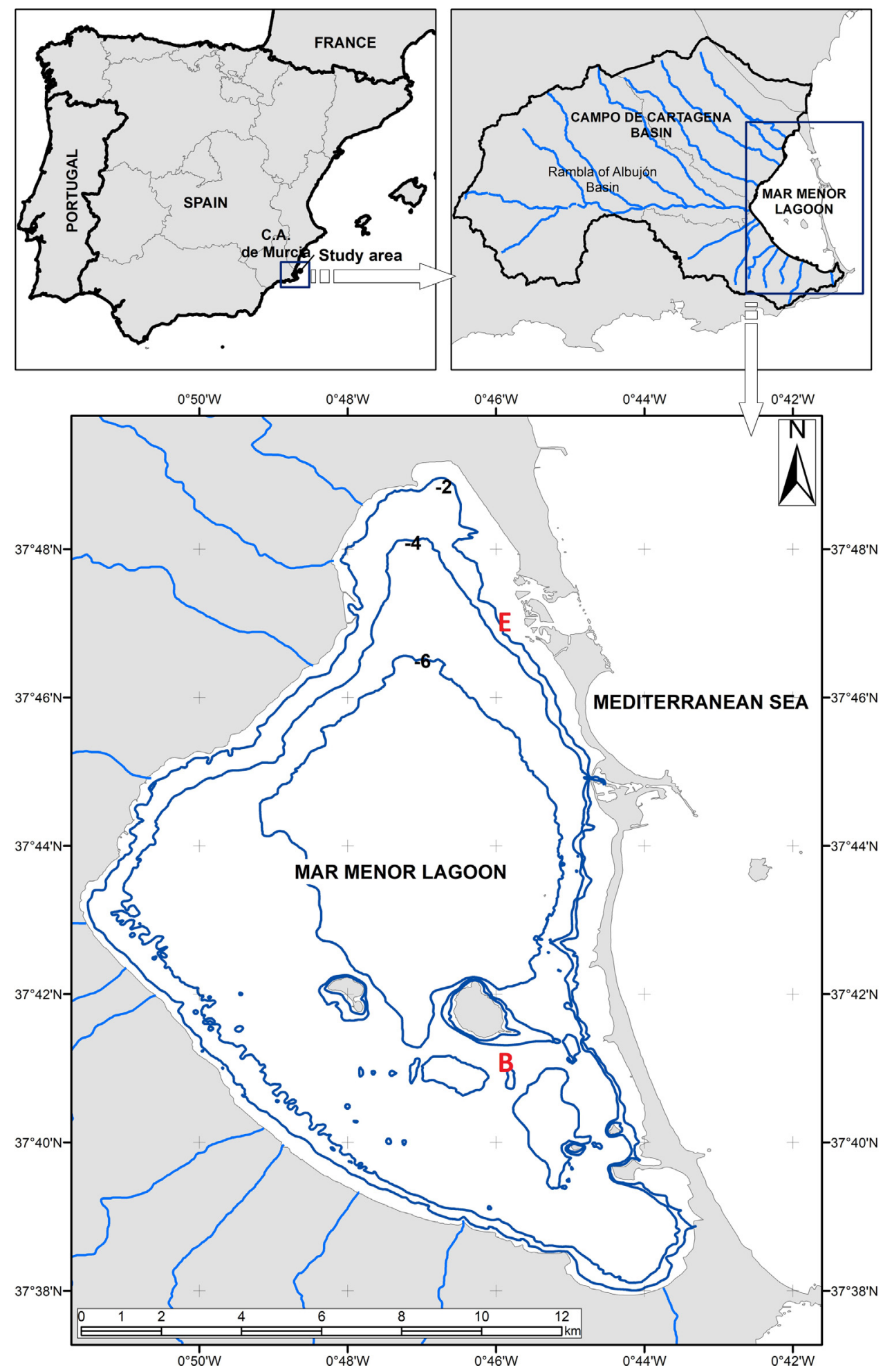

Fig. 1. Map of the Mar Menor lagoon and sampling locations; E: Encañizadas ( $37^{\circ} 46^{\prime} 9.69^{\prime \prime}$, W $\left.0^{\circ} 45^{\prime} 7.79^{\prime \prime}\right)$, $\left(\mathrm{N} 37^{\circ} 46^{\prime} 9.06^{\prime \prime}\right.$, W $0^{\circ} 45^{\prime} 9.31^{\prime \prime}$ ) and B: Barón (N $\left.37^{\circ} 41^{\prime} 45.9^{\prime \prime}, \mathrm{W} 0^{\circ} 45^{\prime} 9.48^{\prime \prime}\right)$

relative abundance of $3.2 \%$; Porifera was represented by one species and a relative abundance of $3.6 \%$; Echinodermata, with one identified species and a very low relative abundance (0.01\%). Finally, the phylum Chordata, which showed a relative abundance of $0.046 \%$ (Fig. 2, Table 2). A clear increase in diversity values was observed Baron samples from 2017 to 2018. In 2018, an increase of richness of mollusks can be observed in these areas. Otherwise,
Encañizadas samples showed a decreased of Shannon diversity values (Table 3).

Cluster analysis and nMDS plots of the species abundances showed the general distribution by years, with the 2017 samples distributed in the upper part of the graph and the 2018 samples in the lower part, and with only the station E2/18 breaking this pattern (Fig. 3). Based on similarities in different stations and year, four main groups were established. Among these groups, 


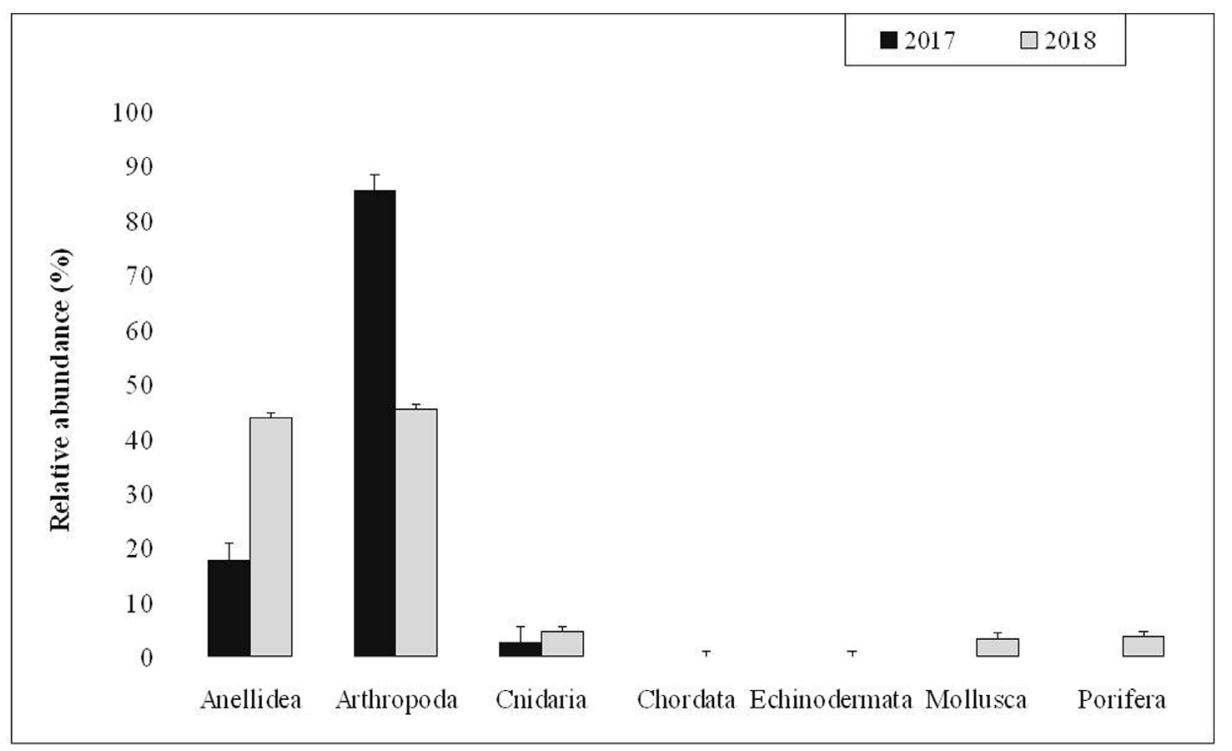

Fig. 2. Relative fouling abundance (\%) by phyla during both experimental years $(2017,2018)$

Table 2

Presence/absence of the species found in the collectors in the Baròn and Encañizada during 2017 and 2018.

\begin{tabular}{|c|c|c|c|c|c|}
\hline Phyla & Species & $\mathrm{B} 1 / 17$ & $\mathrm{E} / 17$ & $\mathrm{~B} / 18$ & $\mathrm{E} / 18$ \\
\hline \multicolumn{5}{|c|}{ Annelid (polychaete) } & $\mathrm{x}$ \\
\hline \multicolumn{6}{|c|}{ Eunice $s p$} \\
\hline & Brania clavata & & $\mathrm{x}$ & $\mathrm{x}$ & \\
\hline & Branchiomma boholense & & $\mathrm{x}$ & $\mathrm{x}$ & \\
\hline & Eulalia viridis & & & & $\mathrm{x}$ \\
\hline & Serpula vermicularis & $\mathrm{x}$ & $\mathrm{x}$ & $\mathrm{x}$ & $\mathrm{x}$ \\
\hline & Serpula concharum & $\mathrm{x}$ & $\mathrm{x}$ & $\mathrm{x}$ & $\mathrm{x}$ \\
\hline & Hydroides elegans & $\mathrm{x}$ & $\mathrm{x}$ & $\mathrm{x}$ & $\mathrm{x}$ \\
\hline & Hydroides dianthus & $\mathrm{x}$ & $\mathrm{x}$ & $\mathrm{x}$ & $\mathrm{x}$ \\
\hline & Syllidea $s p$ & & & $\mathrm{x}$ & \\
\hline & Polyophthalmus pictus & & & $\mathrm{x}$ & $\mathrm{x}$ \\
\hline & Hediste diversicolor & & & & $\mathrm{x}$ \\
\hline \multicolumn{6}{|c|}{ Arthropoda } \\
\hline & Sphaeroma serratum & $\mathrm{x}$ & $\mathrm{x}$ & $\mathrm{x}$ & $\mathrm{x}$ \\
\hline & Cymodoce truncata & $\mathrm{x}$ & $\mathrm{x}$ & $\mathrm{x}$ & $\mathrm{x}$ \\
\hline & Gammarus aequicauda & $\mathrm{x}$ & $\mathrm{x}$ & $\mathrm{x}$ & \\
\hline & Lophogaster typicus & $\mathrm{x}$ & $\mathrm{x}$ & $\mathrm{x}$ & $\mathrm{x}$ \\
\hline & Balanus amphitrite & $\mathrm{x}$ & $\mathrm{x}$ & $\mathrm{x}$ & $\mathrm{x}$ \\
\hline & Geryon longipes & & & $\mathrm{x}$ & \\
\hline \multicolumn{6}{|c|}{ Cnidaria } \\
\hline & Bunodactis verrucosa & & & $\mathrm{x}$ & $\mathrm{x}$ \\
\hline & Aiptasia diaphana & & & $\mathrm{x}$ & $\mathrm{x}$ \\
\hline & Anemonia viridis & $\mathrm{x}$ & $\mathrm{x}$ & $\mathrm{x}$ & $\mathrm{x}$ \\
\hline & Actinia cari & & & $\mathrm{x}$ & \\
\hline \multicolumn{6}{|c|}{ Mollusca } \\
\hline & Tapes decussatus & & & $\mathrm{x}$ & \\
\hline & Dosinia lupinus & & & $\mathrm{x}$ & \\
\hline & Mytilus minimus & & & $\mathrm{x}$ & $\mathrm{x}$ \\
\hline & Hexaples trunculus & & & $\mathrm{x}$ & \\
\hline & Nassarium corniculum & & & $\mathrm{x}$ & \\
\hline \multirow{2}{*}{\multicolumn{6}{|c|}{ 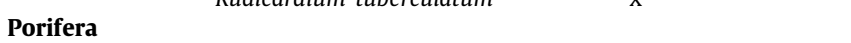 }} \\
\hline & & & & & \\
\hline & Sycon raphanus & & & $\mathrm{x}$ & $\mathrm{x}$ \\
\hline \multicolumn{6}{|c|}{ Echinodermata } \\
\hline & Ophiura ophiura & & $\mathrm{x}$ & & \\
\hline \multicolumn{6}{|c|}{ Chordata } \\
\hline & Stylidea $s p$ & & $\mathrm{x}$ & & \\
\hline
\end{tabular}

the Group 1 (G1) was formed by two collectors in Baron locality in different years, with a similarity above $50 \%$ and the organisms that contributed to this similarity were Balanus Amphitrite and Hydroides dianthus; Group 2 (G2) corresponded to two collectors in Encañizadas in different years with a similarity close to $53 \%$ and the organisms with higher contribution inside the group were Cymodoce truncata and Sphaeroma serratum. Groups 3 (G3) and 4 (G4) presented a clear segregation by years. Samples from 2017 in group 3, with a similarity within group of 66\% showed the same species than G2 contributing to de similarity inside the group, although in this case a new species was incorporated, specifically Hydroides elegans samples correspond to 2018 (G4). The organisms that contributed to the similarity (48\%) were C. truncata, Branchiomma boholense, $H$. elegans and $S$. serratum.(Fig. 3, Table 4).

The SIMPER routine indicated that contribution to the average Bray-Curtis dissimilarity between G1 and G3 were mainly due to the absence in G1 samples of the species Cymodoce truncata and Sphaeroma serratum and in contrast, a great abundance in the G3 stations. The dissimilarity between G3 and G2 was determined by a greater abundance of the same species in G3 versus G2 and the absence of Branchiomma boholense in G3. Balanus amphitrite was very abundant in G1 and scarce in G2. In addition, the organisms C. truncate, B. boholense and S. serratum were absent in G1 and presents in G2, while Hydroides elegans and Hydroides dianthus appeared in G1 and were absent in G2. The dissimilitude between G3 and G4 was marked by the absence of B. boholense and Sycon raphanus in G3 and the higher abundance of the organisms $C$. truncata, $H$. elegans and B. amphitrite in G4, while S. serratum was more abundant in G3. Dissimilarity between G1 and G4 groups was determinate by the absence of $C$. truncate and $B$. boholense in G1 and the difference of abundance of $H$. elegans. Ultimately, we found a similar result between G2 and G4, but in this case the difference was in abundance (Table 5).

The arthropods Cymodoce truncata and Sphaeroma serratum were the most abundant and they were founded in all collectors for both years. The relative biomass obtained from the calculation of the average of biomass of $C$. truncata and $S$. serratum in relation to the total biomass was $7.65 \pm 2.06 \%$ and by collector $\mathrm{B} / 17,8.5$ $\pm 3.9 \%$ for $\mathrm{E} / 17,10.63 \pm 2.81 \%$ for $\mathrm{B} / 18$ and $40.76 \pm 4.24 \%$ for $\mathrm{E} / 18$.

\section{Analysis of the composition and structure of the poly- chaetes}

A total of 2.830 specimens were collected and $99.7 \%$ was identified at a species level. The most represented genera was Hydroides with two species $H$. elegans (Haswell, 1883), which had a relative abundance in 2017 of $5.2 \%$ increasing during 2018 to 
Table 3

Trend of structural indices in both localities and years (a) Number of species (S); Shannon-Wiener index (H'); (d) Margalef index (d); Pielou (J) index.

\begin{tabular}{lllll}
\hline $\begin{array}{l}\text { Diversity } \\
\text { indices }\end{array}$ & Barón 2017 & $\begin{array}{l}\text { Encañizada 2017 } \\
\text { E/17 }\end{array}$ & $\begin{array}{l}\text { Barón 2018 } \\
\text { B/18 }\end{array}$ & $\begin{array}{l}\text { Encañizada 2018 } \\
\text { E/18 }\end{array}$ \\
\hline Taxa_(S) & 11 & 11 & 28 & 18 \\
Shannon (H) & 1.634 & 1.384 & 2.279 & 1.154 \\
Margalef (d) & 1.295 & 1.293 & 3.181 & 2.086 \\
Pielou_(J) & 0.6816 & 0.577 & 0.6767 & 0.3992 \\
\hline
\end{tabular}

Table 4

Results of SIMPER analysis. Species are ranked according to their average contribution to similarity values within groups (G1, G2, G3, and G4). Average abundances, percentage of contribution and percentage of cumulative similarity are also included. A cut-off at a cumulative similarity (\%) of $88 \%$ was applied.

\begin{tabular}{|c|c|c|c|c|c|}
\hline Group & $\begin{array}{l}\text { SIMPER - percent } \\
\text { similarity within group }\end{array}$ & Species & Av.Abund & Contrib\% & Cum.\% \\
\hline \multirow[t]{2}{*}{ G1 } & 49.72 & Balanus amphitrite & 191.50 & 86.86 & 86.86 \\
\hline & & Hydroides dianthus & 38.50 & 6.86 & 93.71 \\
\hline \multirow[t]{2}{*}{ G2 } & 52.73 & Cymodoce truncata & 119.00 & 67.46 & 67.46 \\
\hline & & Sphaeroma serratum & 62.50 & 30.18 & 97.63 \\
\hline \multirow[t]{3}{*}{ G3 } & 66.18 & Cymodoce truncata & 519.50 & 60.05 & 60.05 \\
\hline & & Sphaeroma serratum & 269.75 & 21.28 & 81.33 \\
\hline & & Hydroides elegans & 50.50 & 7.08 & 88.42 \\
\hline \multirow[t]{4}{*}{ G4 } & 47.92 & Cymodoce truncata & 861.67 & 49.35 & 49.35 \\
\hline & & Branchiomma boholense & 823.67 & 21.79 & 71.14 \\
\hline & & Hydroides elegans & 340.33 & 11.50 & 82.64 \\
\hline & & Sphaeroma serratum & 143.67 & 7.38 & 90.02 \\
\hline
\end{tabular}

Table 5

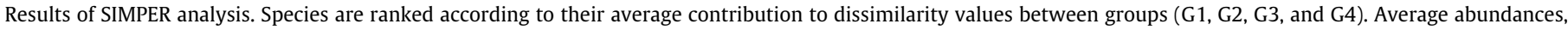
percentage of contribution and percentage of cumulative dissimilarity are also included. A cut-off at a cumulative dissimilarity (\%) of $81 \%$ was applied.

\begin{tabular}{|c|c|c|c|c|c|c|}
\hline Groups & $\begin{array}{l}\text { SIMPER - percent dissimilarity } \\
\text { between groups }\end{array}$ & Species & Av.Abund & Av.Abund & Contrib\% & Cum.\% \\
\hline & & & Group 1 & Group 3 & & \\
\hline \multirow[t]{4}{*}{1,3} & 84.45 & Cymodoce truncata & 0 & 519.50 & 46.25 & 46.25 \\
\hline & & Sphaeroma serratum & 0 & 269.75 & 22.61 & 68.86 \\
\hline & & Balanus amphitrite & 191.5 & 24.75 & 14.36 & 83.23 \\
\hline & & & Group 3 & Group 2 & & \\
\hline \multirow[t]{5}{*}{3,2} & 70.31 & Cymodoce truncata & 519.50 & 119.00 & 43.77 & 43.77 \\
\hline & & Sphaeroma serratum & 269.75 & 62.50 & 20.83 & 64.60 \\
\hline & & Branchiomma boholense & 0 & 111.50 & 11.07 & 75.67 \\
\hline & & Hydroides elegans & 50.50 & 0 & 5.44 & 81.11 \\
\hline & & & Group 1 & Group 2 & & \\
\hline \multirow[t]{7}{*}{1,2} & 95.17 & Balanus amphitrite & 191.50 & 9.00 & 29.10 & 29.10 \\
\hline & & Cymodoce truncata & 0 & 119.00 & 20.18 & 49.28 \\
\hline & & Branchiomma boholense & 0 & 111.50 & 15.56 & 64.83 \\
\hline & & Sphaeroma serratum & 0 & 62.50 & 10.85 & 75.68 \\
\hline & & Hydroides elegans & 54.50 & 0 & 7.18 & 82.86 \\
\hline & & Hydroides dianthus & 38.50 & 0 & 5.51 & 88.37 \\
\hline & & & Group 3 & Group 4 & & \\
\hline \multirow[t]{7}{*}{3,4} & 60.55 & Branchiomma boholense & 0 & 823.67 & 33.52 & 33.52 \\
\hline & & Cymodoce truncata & 519.50 & 861.67 & 14.17 & 47.69 \\
\hline & & Hydroides elegans & 50.50 & 340.33 & 13.21 & 60.89 \\
\hline & & Balanus amphitrite & 24.75 & 274.00 & 9.50 & 70.39 \\
\hline & & Sphaeroma serratum & 269.75 & 143.67 & 6.54 & 76.93 \\
\hline & & Sycon raphanus & 0 & 129.33 & 5.06 & 81.99 \\
\hline & & & Group 1 & Group 4 & & \\
\hline \multirow[t]{5}{*}{1,4} & 90.34 & Cymodoce truncata & 0 & 861.67 & 28.38 & 28.38 \\
\hline & & Branchiomma boholense & 0 & 823.67 & 26.98 & 55.35 \\
\hline & & Hydroides elegans & 54.50 & 340.33 & 11.39 & 66.74 \\
\hline & & Balanus amphitrite & 191.50 & 274.00 & 10.09 & 76.83 \\
\hline & & & Group 2 & Group 4 & & \\
\hline \multirow[t]{4}{*}{2,4} & 80.93 & Cymodoce truncata & 119.00 & 861.67 & 27.32 & 27.32 \\
\hline & & Branchiomma boholense & 111.50 & 823.67 & 26.19 & 53.51 \\
\hline & & Hydroides elegans & 0 & 340.33 & 14.34 & 67.85 \\
\hline & & Balanus amphitrite & 9.00 & 274 & 8.04 & 75.89 \\
\hline
\end{tabular}

11.8\%; and $H$. dianthus (Verrill, 1873) with a relative abundance of $4.6 \%$ during 2017 which decreased to $3.5 \%$ in 2018 . The genera Serpula was represented with two species: S. vermicularis (Linnaeus, 1767), which had a relative abundance in 2017 of $0.9 \%$ and $0.2 \%$ in 2018 and; S. concharum (Langerhans, 1880), with had a relative abundance in 2017 of $0.2 \%$ reduced to $0.1 \%$ in 2018 . (Fig. 4).

The Bray-Curtis similarity analysis (cluster analysis) showed a division into two primary groups, GP1 and GP2, with an internal similarity higher than 55\% in GP1 and $27 \%$ in GP2 (Fig. 5, Table 6). GP1 was in turn divided into two subgroups GP1 A and GP1B, the 
A

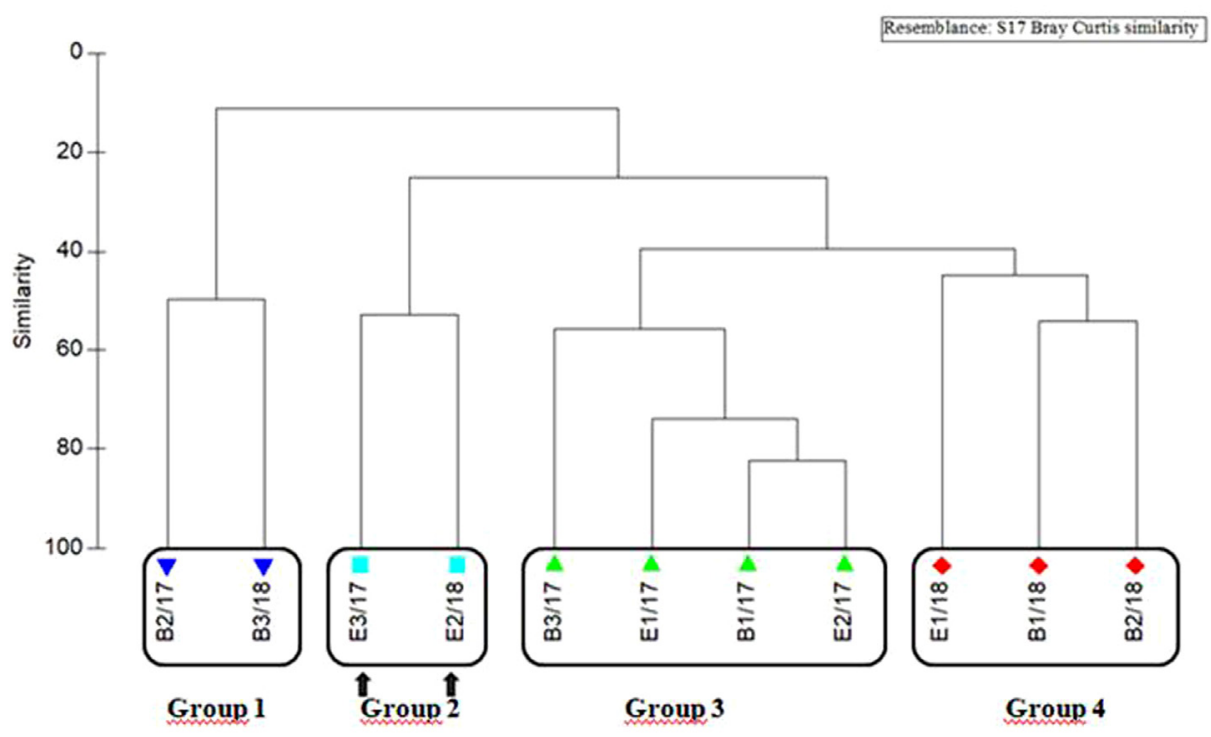

B

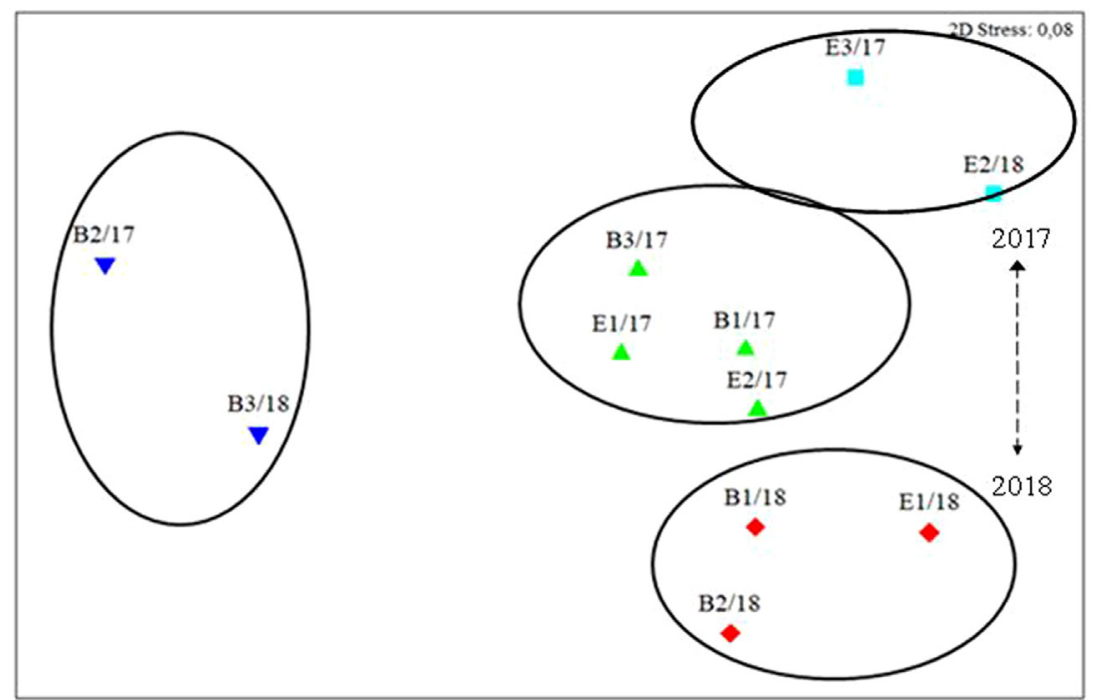

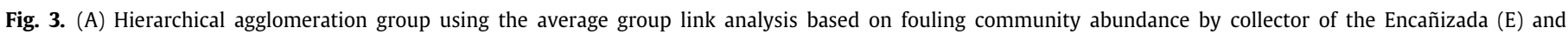

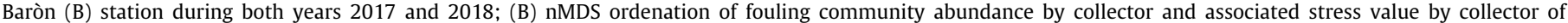
the Encañizada (E) and Baròn (B) station during both years 2017 and 2018.

first one composed by two collectors from Baron locality in the second experimental year (B1/18 and B2/18) with a similarity of $70 \%$, while the subgroups GP1B had a similarity of $60 \%$ and was composed by collectors from both localities, four of them from 2017 and two from 2018. GP2 had a similarity of 15\%. The analysis of the MDS (Fig. 5B) confirms an aggregation between most of the collectors, and shows the isolation of sample B2/17 from the rest of the groups.

The SIMPER procedure showed that the percentage of similarity within GP1 was determined by the presence of Hydroides elegans (Table 7). while the organisms responsible for the similarity within GP2 are Serpula concharum (Table 6).

To evaluate the weight of calcium carbonate, the ratio between the weight of the polychaeta structure tubes and the number of living individuals found was calculated, with ratio values of 13.04 in 2017 and 17.7 in 2018.

\section{Discussion}

During the past decades, the Mar Menor has undergone a deep transformation due to anthropogenic pressure and its consequent direct or indirect effect on the environment. The ensuing alterations affect the structure and composition of communities and in the case of invertebrates, these changes are easily detectable at the taxonomic level of the family (Gimenez-Casalduero et al., 2011). The biotic component, used in studies on natural and/or anthropogenic stress response, is particularly useful to analyse the effects of local disturbances, since the organisms that are part of them have a long life and are relatively sedentary (Thrush and Dayton, 2002).

The fouling communities after the episode of severe eutrophication in the Mar Menor coastal lagoon (Ruiz et al., 2019) were analysed during 2017 and 2018 and 31 taxa at the level of 


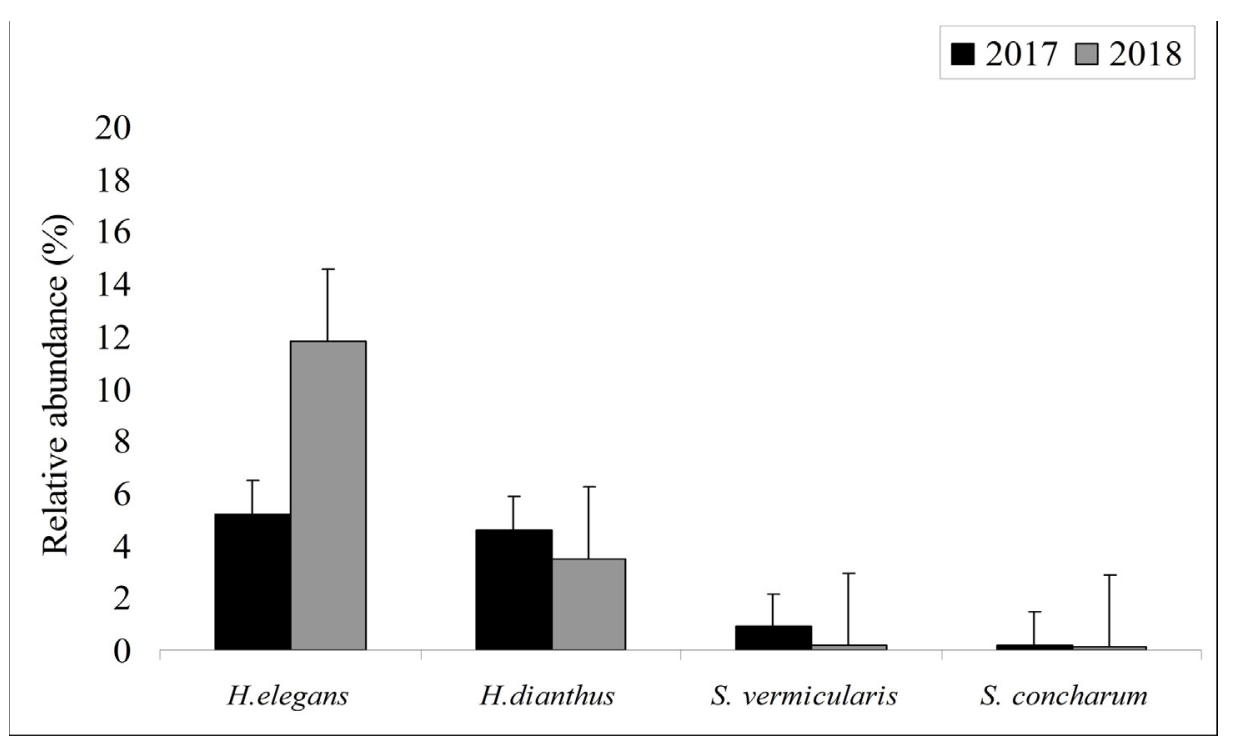

Fig. 4. Relative abundance of the representative fouling polychaeta species in the collectors of the Mar Menor during 2017 and 2018.

Table 6

Results of SIMPER analysis. Polychaeta species are ranked according to their average contribution to similarity values within groups (GP1 and GP2). Average abundances, percentage of contribution and percentage of cumulative similarity are also included. A cut-off at a cumulative similarity (\%) of $92 \%$ was applied.

\begin{tabular}{llllrr}
\hline Group & $\begin{array}{l}\text { SIMPER - percent } \\
\text { similarity within group }\end{array}$ & Species & Av.Abund & Contrib\% & Cum.\% \\
\hline GP1 & 55.33 & Hydroides elegans & 166.50 & 57.48 & 57.48 \\
& & Hydroides dianthus & 64.25 & 35.14 & 92.63 \\
GP2 & 27.19 & Serpula concharum & 1.67 & 100.00 & 100.00 \\
\hline
\end{tabular}

Table 7

Results of SIMPER analysis. Polychaeta species are ranked according to their average contribution to dissimilarity values between groups (GP1 and GP2). Average abundances, percentage of contribution and percentage of cumulative dissimilarity are also included. A cut-off at a cumulative dissimilarity (\%) of $60 \%$ was applied.

\begin{tabular}{|c|c|c|c|c|c|c|}
\hline Groups & $\begin{array}{l}\text { SIMPER - percent dissimilarity } \\
\text { between groups }\end{array}$ & Species & Av.Abund & Av.Abund & Contrib\% & Cum.\% \\
\hline & 92.75 & Hydroides elegans & $\begin{array}{l}\text { Group } 1 \\
166.5\end{array}$ & $\begin{array}{l}\text { Group } 2 \\
0\end{array}$ & 60.05 & 60.05 \\
\hline
\end{tabular}

phylum, genus or species were identified. A low diversity was detected during 2017, but a significant increase in diversity was observed during 2018, with the presence of organism like Branchiomma boholense which is considered an invasive species from the Atlantic very abundant in port areas, or Hexaplex trunculus (Linnaeus, 1758), Mytilus minimus Poli, 1795, Rudicardium tuberculatum Linnaeus, 1758, Dosinia lupinus Linnaeus, 1758, Nassarius corniculum Olivi, 1792, Sycon raphanus Schmidt, 1862, Ophiura ophiura Linnaeus, 1758, Stylidea sp.

Two opportunistic organisms, belonging to the phylum Arthropoda - Sphaeroma serratum and Cymodoce truncata (Afli et al., 2009) - had a constant presence during both years and were dominant in some collectors. Branchiomma boholense were found exclusively in 2018, indicating that this organisms was incorporated later to the fouling community. Low values of the Pielou index in some collectors suggested the dominance of R-strategists species in the community. For example, B. boholense was very abundant only in one collector (E/18) and during 2018, while the more abundant organism for the rest of the collectors, independently of the sampling year, were $C$. truncata and $S$. serratum. Both study sites were characterized by a sandy-muddy bottom with small patches of Cymodocea nodosa. Branchiomma boholense is usually associated to Caulerpa prolifera and C. nodosa (Roman et al., 2009). The larval source for organisms colonization in the collectors must have been from surrounding macrophyte habitat.
On the other hand, C. truncata is common on the Spanish coasts, both in the Atlantic (Drake et al., 1997; Rodríguez-Sánchez et al., 2001) and in the Mediterranean (Castelló and Carballo, 2001). They are usually collected in shallow intertidal and subtidal areas (1-3 $\mathrm{m}$ ) and can be founded living in macrophyte beds and seaweed, dead intertidal corals and in the subtidal over dead barnacles and oyster shells (Khalaji-Pirbalouty et al., 2013). This species is quite common in the Mar Menor coastal lagoon and its prevalence may be associated with the high nutrient content found in the water column (Lloret Barba, 2011). This isopod is mainly herbivorous and solitary and becomes gregarious during the reproductive period, when the male dominates over a high number of females (Wetzel, 2001). S. serratum Fabricius, 1787, often lives in coastal marine or brackish waters, which are subject to variations in salinity (Daguerre de Hureaux, 1966; Charmantier and Charmantier-Daures, 1994).

The invasive species Branchiomma boholense, was the best represented organism of the family Sabellidae, (López and Richter, 2017). The genera Branchiomma Kölliker, 1858 includes approximately 29 species and most of them have an intertropical distribution (Giangrande and Licciano, 2004), with six considered as alien species worldwide (Zenetos et al., 2010). Branchiomma boholense has been described in the Mediterranean area (Link et al., 2009; Minchin et al., 2013; Del Pasqua et al., 2017; Del Pasqua 
A

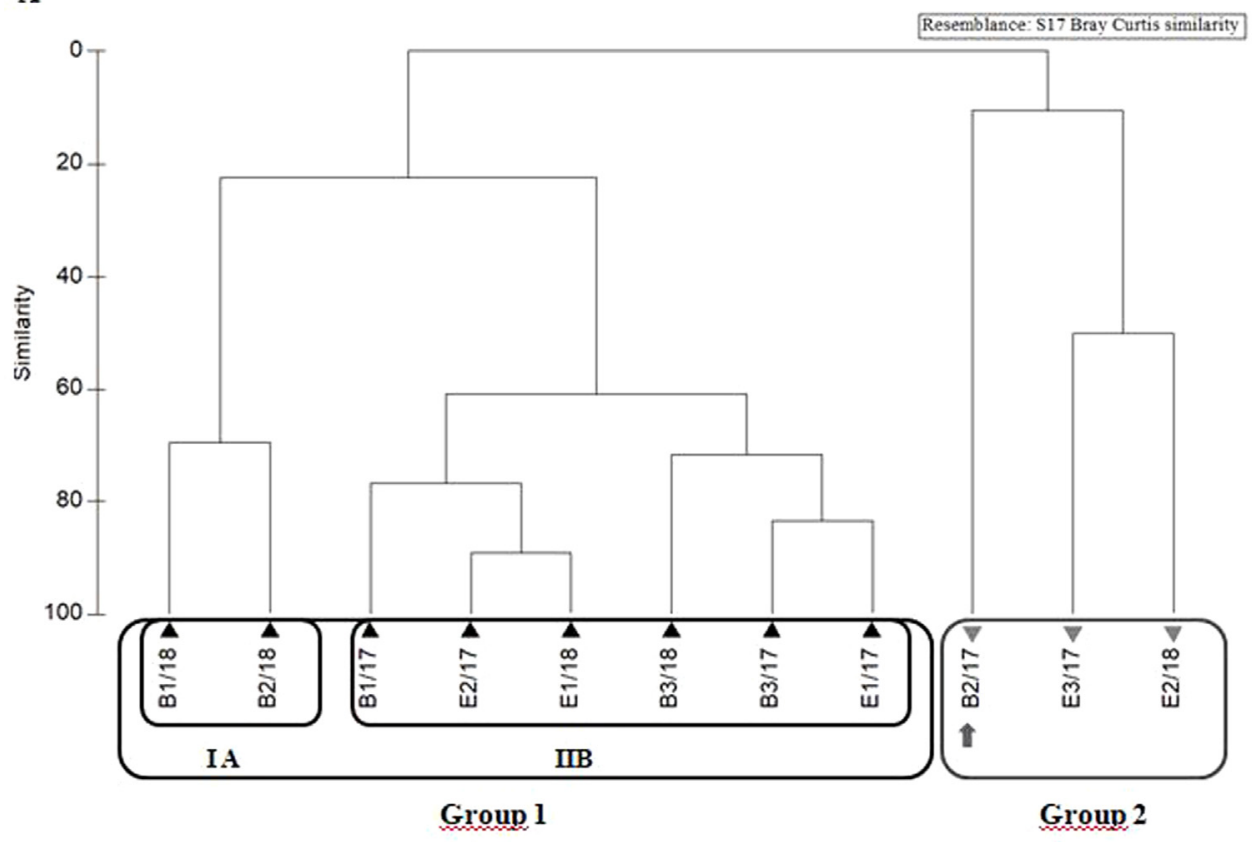

B

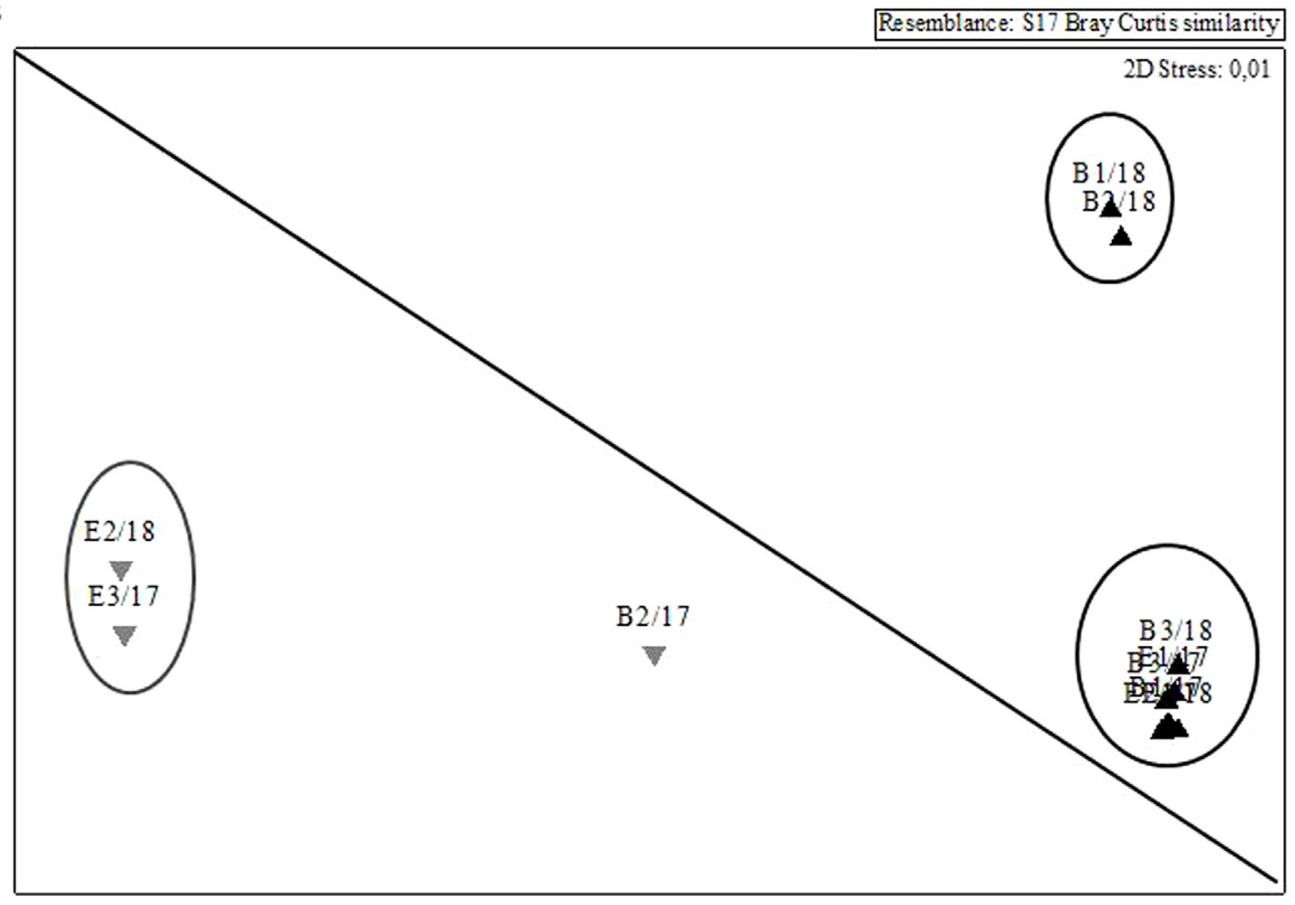

Fig. 5. (A) Hierarchical agglomeration group using the average group link based on polychaete abundance assemblage by collector of the Encañizada (E) and Barón (B) station during both years 2017 and 2018; (B) nMDS ordenation of polychaete abundance assemblage by collector and associated stress value by collector of the Encañizada (E) and Barón (B) station during both years 2017 and 2018.

et al., 2018) and also in the Mar Menor where it was originally confused with Branchiomma bairdi (McIntosh, 1885) because the difficulty to distinguish between both species (Keppel et al., 2015; Arias et al., 2013). The species was originally described in 1878 on the island of Bohol (Philippines) and it is widely distributed in the Indian Ocean and Red Sea (Tovar-Hernández et al., 2009), from where it seems that it enters in the Mediterranean through the Suez Canal. This species has a great adaptability and a fastreproductive rate (Licciano and Giangrande, 2008), features that allow it to adapt to altered conditions. It is highly probable that boating has been the activity that acted like the introduction vector of this species into the Mar Menor. In addition, high water temperature during summer and high salinity of the lagoon have probably favoured the colonization of this species (Roman et al., 2009).

The most abundant serpulids founded in the collectors were Hydroides dianthus and Hydroides elegans, the first represented in both years, while the abundance of the second one increases throughout 2018. On the other hand, Serpula vermicularis and Serpula concharum were represented with low abundance. During 
eutrophic events occurred in the Mar Menor during 2016, pH values reached levels below the threshold of 7.6 which could lead to decline in calcification of invertebrate structure (Álvarez Rogel et al., 2016; Gazeau et al., 2013). But the important growth of species with the formation of massive aggregates (Hydroides elegans, Balanus amphitrite) can be determined by the chemical process favoured in turn by the eutrophication process (Sandonnini et al., 2021).

The presence of polychaetes indicates biomineralization which is an evolutionary adaptation whereby organisms generate inorganic products in the form of minerals used for housing, structure or defence (Hedley, 1956; Batzel et al., 2016). The ratio between the tubes dry weight and the number of living individuals can be an indicator of the formation of reef structures ability for a specific number of specimens. The results of this index showed a lower value in 2017 than 2018, in coincidence with the peak of abundance of Hydroides elegans, a reef-maker species. The species Hydroides dianthus starred in episodes of massive growth in the lagoon. The formations grew on the substrate or on Pinna nobilis shells (Sandonnini et al., 2021). However, in this study this organism only appears in the G1 stations, specifically in Barón, and represented with low abundance. It is possible that the collectors used were not the ideal substrate for the colonization of this species.

The studied community was mainly dominated by suspensionfeeder species (especially during 2018). Most of them were typical from an unstable environment and associated with physicalchemical disturbances. This is in contrast with the communities settled in the same kind of collectors in other Spanish Mediterranean sites. In the Columbretes Islands Marine Reserve (NW Mediterranean), a well preserved, open sea site, and around the Balearic islands, Mollusca was the dominant group followed by Crustacea, (D. K. Kersting, I. E. Hendriks, pers. obs.). It is probable that the composition of the species will change with time in a situation of improvement of the ecological state of the lagoon. The results observed in 2018 could be interpreted as a possible recovery of the communities. During that year, taxa such as cnidarians, porifera or echinoderms which had disappeared from this environment in 2017 samples, began to appear again. This could be a symptom of fouling community recovery before the recurrent episode of eutrophication in 2019

The presence of filter-feeding Mollusca can help to improve the water quality in the Mar Menor (Salazar-Vallejo, 2000). After years of anthropogenic pressures, fouling community has been affected and modified, with changes in the structure in the polychaete assemblage, and it had been altered both, the presence and abundance of species over time.

\section{CRediT authorship contribution statement}

Jessica Sandonnini: Conceptualization, Processed samples, Data analysing, Writing the manuscriptpt. Yoana Del Pilar Ruso: Dra, -Processed samples, Data analysing, Contributing to the manuscript. Emilio Cortés Melendreras: Collected samples and contributing and review the manuscript. Carmen Barberá: Collected samples and contributing to the manuscripts. Iris E. Hendriks: Collector design and contributing and review the manuscripts. Diego Kurt Kersting: Collector design and contributing and review the manuscripts. Francisca Giménez Casalduero: Conceptualization, Samples collection, Data analysing, Writing and review the manuscript.

\section{Declaration of competing interest}

The authors declare that they have no known competing financial interests or personal relationships that could have appeared to influence the work reported in this paper.

\section{Acknowledgements}

We would like to thank the Department of Marine Science and Applied Biology of the University of Alicante especially V. Pardo, R. Canales, and E. Abellan, the University of Murcia AQUARIUM team for their field and laboratory support during the present research and Dr. F, Gomaríz Castillo for his help in improving the map. This study was supported by the research fund of the University of Alicante and Murcia University Aquarium.

\section{References}

Afli, A., Boufahja, F., Sadraoui, S., Ben Mustapha, K., Aissa, P., Mrabet, R., 2009. Functional organization of the benthic macrofauna in the Bizerte lagoon (SW Mediterranean Sea), semi-enclosed area subject to strong environmental/anthropogenic variations. Cah. Biol. Mar. 50 (2), 105.

Aguilar Escribano, J., Gimenez-Casalduero, F., Mas Hernández, J., RamosEsplá, A.A., 2016. Evaluación del estado y composición de la Comunidad Fitoplanctónica de las aguas del Mar Menor, Murcia (mayo de 2016). Technical Report, https://rua.ua.es/dspace/bitstream/10045/57169/2/Mar_Menor_ Mayo_2016.pdf.

Álvarez Rogel, J., González Alcaraz, M.N., Conesa Alcaraz, H.M., Tercero Gómez, M.D.C., Párraga Aguado, I.M., María Cervantes, A., Jiménez Cárceles, F.J., 2016. Eutrofización y contaminación por residuos mineros en humedales del Mar Menor: comprendiendo los procesos biogeoquímicos para plantear posibles actuaciones de manejo.

Arias, A., Giangrande, A., Gambi, M.C., Anadón, N., 2013. Biology and new records of the invasive species Branchiomma bairdi (Annelida: Sabellidae) in the Mediterranean Sea. Mediterranean Mar. Sci. 14 (1), 162-171.

Batzel, G., Nedved, B.T., Hadfield, M.G., 2016. Expression and localization of carbonic anhydrase genes in the serpulid polychaete hydroides elegans. Biol. Bull. 231 (3), 175-184.

Belando, M.D., Bernardeau-Esteller, J., García-Muñoz, R., Ramos-Segura, A., Santos-Echeandía, J., García-Moreno, P., et al., 2017. Evaluación del Estado de Conservación de las Praderas de Cymodocea nodosa en la Laguna Costera del Mar Menor. 2014-2016. Instituto Español de Oceanografía y Asociación de Naturalistas del Sureste, Murcia, p. 157

Carreño, M.F., Esteve, M.A., Martinez, J., Palazón, J.A., Pardo, M.T., 2008. Habitat changes in coastal wetlands associated to hydrological changes in the watershed. Estuarine. Coast. Shelf Sci. 77, 475-483.

Castelló, J., Carballo, J.L., 2001. Isopod fauna, excluding Epicaridea, from the Strait of Gibraltar and nearby areas (Southern Iberian Peninsula). Sci. Mar. 65 (3), 221-241.

Charmantier, G., Charmantier-Daures, M., 1994. Ontogeny of osmoregulation and salinity tolerance in the isopod crustacean Sphaeroma serratum. Mar. Ecol. Prog. Ser. 114, 93.

Clarke, K.R., Warwick, R.M., 2001. Change in Marine Communities: An Approach to Statistical Analysis and Interpretation, Segunda edición Plymouth Marine Laboratory, Plymouth, Reino Unido.172, p. 9.

Conesa, H.M., Jiménez-Cárceles, F.J., 2007. The Mar Menor lagoon (SE Spain): A singular natural ecosystem threatened by human activities. Mar. Pollut. Bull. 54 (7), 839-849.

Daguerre de Hureaux, N., 1966. Etude du cycle biologique de Sphaeroma serratum au Maroc. Bull. Soc. Sci. Nat. Phys. Maroc. 46, 19-52.

Del Pasqua, M., Lezzi, M., Licciano, M., Giangrande, A., 2017. Desarrollo larval y crecimiento postlarval de Branchiomma bairdi (Annelida: Sabellidae) de una población mediterránea. Invertebr. Biol. Inv. Biol. 136 (2), 207-216.

Del Pasqua, M., Schulze, A., Tovar-Hernández, M.A., Keppel, E., Lezzi, M., Gambi, M.C., Giangrande, A., 2018. Clarifying the taxonomic status of the alien species Branchiomma bairdi and Branchiomma boholense (Annelida: Sabellidae) using molecular and morphological evidence. PLoS One 13 (5).

Drake, P., Arias, A.M., Conradi, M., 1997. In: Viéitez, J.M., Junoy, J. (Eds.), Aportación al conocimiento de la macrofauna supra y epibentónica de los caños mareales de la bahía de Cádiz (España). En: Investigaciones sobre el bentos marino. IX Simposio ibérico de estudios del bentos marino (19-23 de febrero, 1996. Alcalá de Henares, Madrid, España). Publicaciones Especiales. Instituto Español de Oceanografía 23, pp. 133-141.

Gazeau, F., Parker, L.M., Comeau, S., Gattuso, J.P., O'Connor, W.A., Martin, S., et al., 2013. Impacts of ocean acidification on marine shelled molluscs. Mar. Biol. 160 (8), 2207-2245.

Giangrande, A., Licciano, M., 2004. Factors influencing latitudinal pattern of biodiversity: an example using Sabellidae (Annelida, Polychaeta). Biodivers. Conserv. 13 (9), 1633-1646. 
Giménez-Casalduero, F., Gomariz-Castillo, F., Alonso-Sarría, F., Cortés, E., Izquierdo-Muñoz, A., Ramos-Esplá, A.A., 2020. Pinna nobilis in the Mar Menor coastal lagoon: a story of colonization and uncertainty. Mar. Ecol. Prog. Ser. 652, 77-94.

Gimenez-Casalduero, F., Rodríguez-Ruiz, S., Vivas, M., Ramos Esplá, A.A., 2011. Variaciones de las características estructurales de la comunidad de poliquetos asociada a dos fondos de maërl del litoral alicantino (sudeste de la península Ibérica). Boletín. Inst. Esp. Oceanogr. 17 (1 y 2), 191-201.

Gómez, M.D.C.T., 2017. Procesos biogeoquímicos y eliminación de nitrógeno y fósforo de aguas eutrofizadas en humedales del entorno del Mar Menor: resultados experimentales en mesocosmos (Doctoral dissertation). Universidad Politécnica de Cartagena.

Gray, J.S., 1981. The Ecology of Marine Sediments. An Introduction to the Structure and Function of Benthic Communities. Cambridge University Press, p. 185.

Hargrave, B.T., Thiel, H., 1983. Assessment of pollution-induced changes in benthic community structure. Mar. Pollut. Bull. 14 (2), 41-46.

Hedley, R.H., 1956. Studies on serpulid tube formation. I. The secretion of the calcareous and organic components of the tube by pomatoceros triqueter. Q. J. Microsc. Sci. 97, 411-419.

Keppel, E., Tovar Hernández, M.A., Ruiz, G.M., 2015. First record and establishment of Branchiomma coheni (Polychaeta: Sabellidae) in the Atlantic Ocean and review of non indigenous species of the genus. Zootaxa.

Kersting, et al., 2020. Recruitment disruption and the role of unaffected populations for potential recovery after the Pinna nobilis mass mortality event. Front. Mar. Sci. http://dx.doi.org/10.3389/fmars.2020.594378.

Khalaji-Pirbalouty, V., Bruce, N.L., Waegele, J.W., 2013. T he genus Cymodoce Leach, 1814 (Crustacea: Isopoda: Sphaeromatidae). Zootaxa 3686 (5), 501-533.

Licciano, M., Giangrande, A., 2008. The genus Branchiomma (Polychaeta: Sabellidae) in the Mediterranean Sea, with the description of B. maerli n. sp. Sci. Mar. 72 (2), 383-391.

Link, H., Nishi, E., Tanaka, K., Bastida-Zavala, R., Kupriyanova, E.K., 2009. Hydroides dianthus (Polychaeta: Serpulidae), and alien species introduced into Tokyo Bay, Japan. Mar. Biodivers. Rec. 2, 1-5.

Lloret Barba, J.I., 2011. El papel de las comunidades bentónicas del Mar Menor (SE de España) en el procesado de nutrientes y la resistencia del ecosistema al proceso de eutrofización.

López, E., Richter, A., 2017. Non-indigenous species (NIS) of polychaetes (Annelida: Polychaeta) from the Atlantic and Mediterranean coasts of the Iberian Peninsula: an annotated checklist. Helgoland Mar. Res. 71 (1), 19.

Magurran, A.E., 1988. Ecological Diversity and its Measurement. Princeton University Press, New Jersey, p. 179.

Marín-Guirao, L., Cesar, A., Marín, A., Vita, R., 2005. Assessment of sediment metal contamination in the Mar Menor coastal lagoon (SE Spain): Metal distribution, toxicity, bioaccumulation and benthic community structure. Ciencias Mar. 31 (2), 413-428.

Martinez Fernandez, J., Esteve, M.A., 2000. Estimación de la contaminación agrícola en el Mar Menor mediante un modelo de simulación dinámica. Mediterranea 17, 19-25.

Martinez-Fernandez, J., Fitz, C., Esteve-Selma, M.A., Guaita, N., Martinez-Lopez, J., 2014. Modelización del efecto de los cambios de uso sobre los flujos de nutrientes en cuencas agrícolas costeras: el caso del Mar Menor (Sudeste de España). Rev. Ecosistemas 22 (3), 84-94.

Mayer-Pinto, M., Junqueira, A.O.R., 2003. Effects of organic pollution on the initial development of fouling communities in a tropical bay, Brazil. Mar. Pollut. Bull. 46 (11), 1495-1503.

Meyer-Reil, L.A., Koster, M., 2000. Eutrophication of marine waters: Effects of benthic microbial communities. Mar. Pollut. Bull. 41, 255-263.

Minchin, D., Cook, E., Clark, P., 2013. Alien species in British brackish and marine waters. Aquat. Invasions 8 (1), 3-19.

Moran, P.J., Grant, T.R., 1991. Transference of marine fouling communities between polluted and unpolluted sites: impact on structure. Environ. Pollut. $72,89-102$.

Murray, S.N., Littler, M.M., 1978. Patterns of algal succession in a perturbated marine intertidal community. J. Phycol. 14, 506-512.
Pardo, M.T., Esteve, M.A., Carreño, M.F., Martínez, J., Miñano, J., Rodríguez, S., 2004. Análisis de los cambios paisajísticos en los humedales costeros del Mar Menor (Murcia, SE Ibérico) mediante técnicas de teledetección ambiental. In: Conesa, C., Álvarez Rogel, J., Martínez Guevera, J.B. (Eds.), Medio Ambiente, Recursos y Riesgos Naturales. Análisis mediante metodología SIG y Teledetección. Servicio de Publicaciones Universidad de Murcia, Murcia, pp. 421-434.

Pearson, T.H., Rosenberg, R., 1978. Macrobenthic succession in relation to organic enrichment and pollution of the marine environment. Oceanogr. Mar. Biol. Annu. Rev. 16, 229-311.

Rastetter, E.B., Cooke, W.J., 1979. Responses of marine fouling communities to sewage abatement in Kaneohe Bay, Hawaii. Mar. Biol. 53, 271-280.

Richmond, M.D., Seed, R., 1991. A review of marine macrofouling communities with special reference to animal fouling. Biofouling 3, 151-168.

Rodríguez-Sánchez, L., Serna, E., Junoy, J., 2001. Crustáceos isópodos de la campaña oceanográfica Fauna I (sur de la península Ibérica). En: XI Simposio ibérico de estudios del bentos marino (22-25 de febrero, 2000. Torremolinos, Málaga, España). J. E. García Raso (ed.). Boletín. Instituto Español de Oceanografía 17 (1-2): 149-161.

Roman, S., Perez-Ruzafa, A., Lopez, E., 2009. First record in the Western Mediterranean Sea of Branchiomma boholense (Grube, 1878)(Polychaeta: Sabellidae), an alien species of Indo-Pacific origin. Cah. Biol. Mar. 50 (3), 241-250.

Ruiz, J.M., León, V.M., Marín-Guirao, L., Giménez-Casalduero, F., Alvárez-Rogel, J., Esteve-Selma, M.A., Martínez Fernández, J., 2019. Informe de síntesis sobre el estado actual del Mar Menor y sus causas en relación a los contenidos de nutrientes). In: Projects of Sustainability and Conservation of Mar Menor Lagoon and its Basin. Universidad de Alicante, Alicante, Spain.

Salazar-Vallejo, S.I., 2000. Contaminación Marina: Métodos de Evaluación Biológica. Centro de Investigaciones de Quintana Roo Chetumal, México. Fondo de Publicaciones y Ediciones Gobierno de Quintana Roo.

Sandonnini, J., Del-Pilar-Ruso, Y., Cortés Melendreras, E., Gimenez-Casalduero, F., 2021. Massive aggregations of Serpulidae associated with eutrophication of the Mar Menor, southeast Iberian Peninsula.

Shannon, C.E., Weaver, W., 1963. The Mathematical Theory of Communication. The University of Illinois Press (Urban), Illinois, pp. 1-132.

Swan, E.F., 1950. The calcareous tube secreting glands of the serpulid polychaetes. J. Morphol. 86, 285-314.

Ten Hove, H.A., Wolf, P.S., 1984. Family Serpulidae Johnston, 1865. In: Uebelacker, J.M., Johnson, P.G. (Eds.), Taxonomic Guide to the Polychaetes of the Northern Gulf of Mexico. Final Report to the Minerals Management Service, Contract 14-12-001-29091. Barry A Vittor \& Ass Inc Mobile, Alabama, pp. $1-34$.

TenHove, H.A., Kupriyanova, E.K., 2009. Taxonomy of Serpulidae (Annelida, Polychaeta): the state of affairs. Zootaxa 2036 (1), 1-126.

Thrush, S.F., Dayton, P.K., 2002. Perturbación de los hábitats bentónicos marinos por arrastre y dragado: implicaciones para la biodiversidad marina. Rev. Anual Ecol. Sist. 33 (1), 449-473.

Tovar-Hernández, M.A., Méndez, N., Salgado-Barragán, J., 2009. Branchiomma bairdi: a Caribbean hermaphrodite fan worm in the south-eastern Gulf of California (Polychaeta: Sabellidae). Mar. Biodivers. Rec. 2.

Velasco, J., LLoret, J., Millan, A., Marin, A., Barahona, J., Abellán, P., Sánchez Fernández, D., 2006. Nutrient and pajrticulate inputs into the Mar Menor lagoon (SE Spain) from an intensive agricultural watershed. Water, Air Soil Pollut. 176, 37-56.

Wetzel, Robert G., 2001. Limnology: Lake and River Ecosystems. gulf professional publishing.

WoRMS Editorial Board, 2019. World register of marine species. Available from: http://www.marinespecies.org.

Zenetos, A., Gofas, S., Verlaque, M., Çinar, M.E., Garcia Raso, J.E., et al., 2010. Alien species in the Mediterranean Sea by 2010. A contribution to the application of European Union's Marine Strategy Framework Directive (MSFD). Part I. Spatial distribution. Mediterr. Mar. Sci. 11 (2), 318-493.

Zibrowius, H., 1992. Ongoing modification of the mediterranean marine fauna and flora by the establishment of exotic species. Mésogée 51, 83-107.

Zibrowius, H., 1994. Introduced invertebrates: examples of success and nuisance in the European Atlantic and in the Mediterranean. European Commission 15309, 44-49.

Zibrowius, H., Thorp, C.H., 1989. A review of the alien serpulid and spirorbid polychaetes in the British Isles. Cah. Biol. Mar. 30, 271-285. 